\title{
Translation of Utterances which Accommodate Responses of Expressive Criticizing and Apologizing Speech Acts
}

\author{
Ramadan Adianto (iD $\square$ 1, M.R. Nababan (iD 2, Djatmika (iD) 3 \\ ${ }^{1}$ Magister of Linguistics, Sebelas Maret University, Indonesia \\ ${ }^{2}$ Professor of Translation Studies, English Language and Literature, Faculty of Cultural Sciences, Sebelas Maret University, \\ Indonesia \\ ${ }^{3}$ Professor of Pragmatics, English Language and Literature, Faculty of Cultural Sciences, Sebelas Maret University, Indonesia \\ $\triangle$ Corresponding Author: Ramadan Adianto, E-mail: ramadan.adiantob@gmail.com
}

\section{ARTICLE INFORMATION ABSTRACT}

Received: December 08, 2020

Accepted: February 14, 2021

Volume: 4

Issue: 2

DOI: $10.32996 /$ ijllt.2021.4.2.12

\section{KEYWORDS}

Expressive speech act, response, accuracy
There are a lot of foreign novels in Indonesia that are written in English. Indonesians who do not have enough knowledge about the English language need Indonesian translation. Thus, having a translator must be considered when translating a novel, most especially the response of expressive speech acts. This article observes the types of response towards expressive criticizing and apologizing speech acts. It also observes the translation technique used to translate a response of specific expressive speech acts and its quality in terms of accuracy. This research employs descriptive qualitative method with content analysis and Focus Group Discussion (FGD henceforth). Also, content analysis was used to categorize the types of responses. In addition, FGD was used to determine the translation technique and its accuracy. The researcher applied purposive sampling to determine the data. The data are the utterances collected through content analysis. The researcher validated the data through the use of source triangulation and methodological triangulation. The data are limited from the four main characters in the novel. The finding shows that from 57 data, there are 18 types of responses. In addition, there are 14 translation techniques used. Furthermore, the accuracy score is 2.77 .

\section{Introduction}

Nowadays, there are a lot of literary works from foreign countries and most of them use the English language. One of these literary works is novel. Indonesian people who's English proficiency is not good have difficulties to enjoy reading a novel. Toovercome this problem, they need a novel which is translated into Indonesian. The translator cannot carelessly translate the novel without paying attention on the different aspects of the novel. One of the aspects is the dialogues between the characters.. The utterances in the dialogues are not only utterances all the time, but also can contain the speakers' intentions. That utterance is a speech act. A speech act is correlated with the psychological emotion of the speaker is usually called as expressive speech acts. Translating speech acts and its response is not an easy task to do. The translators do not only translate the utterances but also the speaker's physiological emotion. The translator also needs to pay attention to the appropriate dictions, words, phrases, or clauses for its target readers. It means that the translator not only should have language competence but also cultural competence.

There are researches about speech act conducted by Limyana (2014), Mansur (2014), Hapsari (2016) and Putri (2017) which discussed specific speech acts translation but none of them discussed about expressive speech act. Furthermore, Fitriana (2014) and Wahyudi (2016) discussed a translation of expressive speech acts. Finally, it can be concluded that there are gaps to discuss on expressive speech act in more detailed and its response. Hence, the study discusses on the translation of a sentence which accommodates a response of criticizing and apologizing expressive speech acts. Furthermore, the researcher also analyses the translation quality in term of the accuracy.

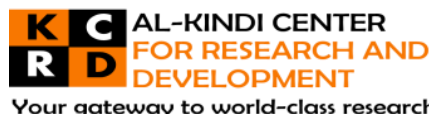

Your gateway to world-class research

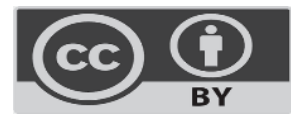

Published by Al-Kindi Center for Research and Development. Copyright (c) the author(s). This open access article is distributed under a Creative Commons Attribution (CC-BY) 4.0 license 


\section{Literature Review 2.1 Speech Act}

Speech acts is a domain of pragmatics, which concerns with the ways of words andcan be used not only to present information but also to do an action. Furthermore, Searle (1979) and Yule (1996) pointed out that speech act is an action which is also represented in utterance. Searle (1979:12-16) explains that there are five categories of speech acts. They are assertive, directive, commissive, expressive, and declarative. expressive speech acts are used to represent speaker's feeling.

Searle (1979:15) explains that expressive speech acts can be categorized as follow: thanking, congratulating, apologizing, condolence, deploring, and welcoming. In addition, Yule (1996:53) explains that pleasure, pain, likes, dislikes, joy or sorrow belongs to expressive speech acts. Djatmika (2016:18) adds that thanking, humiliating, apologizing, saying hello, saying goodbye, praising, blaming, mocking, and condolence are verbs used to accommodate expressive speech acts.

As explained in the above, this article discusses a response of criticizing and apologizing expressive speech acts. Thus, a response of speech act is necessarily needed to build good communication environment between the speaker and the hearer. Subandi (1982:50) explains that "a response or feedback have a great impact on how well or not the communication". Poerdawarminta (1993:43) explains that a response is a feedback, reaction, and answer of a speech that has been uttered previously. It means that the response can be verbal or non - verbal, however in this article non - verbal responses are ignored because they do not have major impacts in the discussion.

\subsection{Translation, Translation Techniques and Translation Quality}

Nida and Taber (1982:12) and Newmark (1988:5) pointed out that translation is a process of delivering messages from one language (source language) to another (target language) without sacrificing the form and equivalence of meaning. Therefore, in doing so the translator must have adequate bilingual skills, grammar systems and must also have profound knowledge of cultural systems in a language used in the text.

In translation research, it cannot be separated from translation techniques. The use of specific translation technique can determine the translation quality. Molina and Albir (2002:509) explained that translation techniques have five characteristics, they are: it affects the result of the translation, it is classified by comparison with the original, it affects the micro-units of text, it is by nature discursive and contextual, and finally, it is functional. In other words, the use of translation techniques will greatly affect the results of the translation, the techniques are classified by comparison with the text of Source Text (ST). The use of such techniques at the micro level are not interrelated but based on particular context, and the use of translation techniques is functional. Furthermore, Molina and Albir (2002:509-511) described several translation techniques as follows: (1) Adaptation; (2) Amplification; (3) Borrowing; (4) Calque; (5) Compensation; (6) Description; (7) Discursive Creation; (8) Established Equivalent; (9) Generalization; (10) Linguistic Amplification; (11) Linguistic Compression; (12) Literal Translation; (13) Modulation; (14) Particularization; (15) Reduction; (16) Substitution; (17) Transposition; and (18) Variation.

Newmark (1988:184) states that 'translation quality assessment is a very important in the process of translation and it becomes a significant link between translation theory and its practice. Hence, to see the link between translation theory and its practice is through translation quality parameters. Nababan, Nuraeni dan Sumardiono (2012:50) stated that 'to assess the translation quality, the researcher needs to pay attention on three aspects, they are accuracy, acceptability and readability.Accuracy is related to the equivalent between ST and TT. In addition, acceptability is about translated text that is in accordance with rules, norms, and cultures prevailing in the target language. Lastly, readability in translation is about how easily a translated text can be understood by the target readers.

\section{Methodology}

This article employs descriptive qualitative method. It means that the researcher collects the data, analyzes, and draws a conclusion based on existing phenomena (Bogdan \& Biklen as cited in Creswell, 2003:171). The data of this article are sentences which accommodate response of expressive speech acts. The data are limited to the sentences which accommodates response of criticizing and apologizing expressive speech acts uttered by four main characters. The four main characters are Jacob, Miss Peregrine, Emma and Golan. They are chosen because they have the most contribution in the story. Specifically, the source of data is a novel entitled Miss Peregrine's Home for Peculiar Children. The researcher chooses that novel because the novel provides sufficient data in form of sentences which accommodates response of expressive speech acts.

The researcher obtained the data through content analysis and FGD (Focus Group Discussion). In the content analysis stage, the researcher took a note of data that there is in accordance with research problems. In addition, the researcher and the respondents 
determined the translation techniques used and the translation accuracy quality of a sentence which accommodates response of criticizing and apologizing expressive speech acts using questionnaires media in the FGD phase. The researcher provided the data and questions about the translation techniques and the translation accuracy quality in the questionnaires. The researcher used translation quality assessment parameter proposed by Nababan, Nuraeni, and Sumardiono (2012:50) to assess the accuracy. The parameter is as follows:

Table 1. Accuracy Assessment Instrument

\begin{tabular}{lll}
$\begin{array}{l}\text { Translation } \\
\text { Categories }\end{array}$ & Score & Quality Parameters \\
\hline Accurate & $\mathbf{3}$ & $\begin{array}{l}\text { The meaning of words, technical terms, phrases, clauses, sentences or source } \\
\text { language texts are accurately translated into target language; without any } \\
\text { distortion of meaning. }\end{array}$ \\
\hline Less Accurate & $\mathbf{2}$ & $\begin{array}{l}\text { The majority of words, technical terms, phrases, clauses, sentences or source } \\
\text { language texts are accurately translated into target language. However, there } \\
\text { is a distortion of meaning or ambiguity or omitted meaning, which interfere } \\
\text { the text message. }\end{array}$ \\
\hline Not Accurate & $\mathbf{1}$ & $\begin{array}{l}\text { The meaning of words, technical terms, phrases, clauses, sentences or source } \\
\text { language texts are not accurately translated into target language or omitted. }\end{array}$ \\
\hline
\end{tabular}

Henceforth, the collected data are validated by using source triangulation and methodological triangulation. In addition, data were analyzed using domain analysis, taxonomy, and componential and cultural theme findings (Spradley, 1980).

\section{Results and Discussion}

Based on the research problems and limitations mentioned in the previous part, the researcher found out that there are 57 data of sentences which accommodate response of criticizing and apologizing expressive speech acts. From the 57 data, there were 4 categories of speech act found: assertive, directive, commissive, and expressive. Moreover, the researcher also found that there are 14 translation techniques used to translate sentences which accommodate response of criticizing and apologizing expressive speech acts. In addition, the average score for the accuracy is 2.77 and it means that the translation of sentence which accommodates response of criticizing and apologizing expressive speech acts is accurate.

\subsection{Response of an Expressive Speech act}

According to Poerdawarminta (1993:43), she explains about a response whether verbal or non - verbal. In addition, using a base theory about speech act from Searle (1979:15), Yule (1996:53) and Djatmika (2016:18), the researcher found out that there are 3 assertive speech acts, 5 directive speech acts, 3 commissive speech acts, and 6 expressive speech acts as the response of criticizing and apologizing expressive speech acts. Below is the detailed representation of speech acts:

Figure 1. Responses in expressive speech act

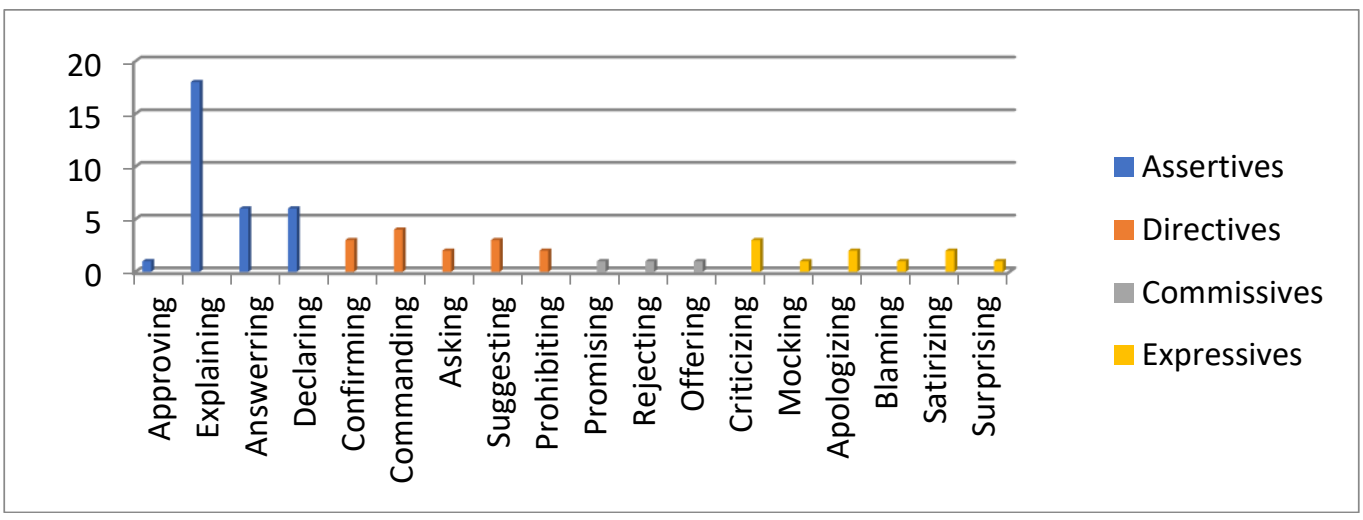

The above figure explains the 4 categories of speech acts found: assertive, directive, commissive, and expressive. In addition, in assertive category there are approving, explaining, answering, and declaring speech acts. Moreover, in directive category there are confirming, commanding, asking, suggesting, and prohibiting speech acts. Furthermore, in commissive category there are promising, rejecting, and offering speech acts. Lastly, from expressive category there are criticizing, mocking, apologizing, blaming, 
satirizing, and surprising speech acts. Below are the examples of sentences which accommodate response of criticizing and apologizing expressive speech acts:

Assertive - Approving

\begin{tabular}{ll}
\hline Jacob: & "That word again," I said. "When we first met, Emma accused me of being one." \\
P- D- & \\
\hline Peregrine: & "I might have thought the same thing, if I hadn't observed you beforehand." \\
P+ D- &
\end{tabular}

The participants from the abovementioned dialogues are Jacob and Miss Peregrine. Jacob is criticizing about him being accused for something that he did not know. The criticizing utterance can be seen from the phrases "accused me of being one". Furthermore, Miss Peregrine as the hearer gives a response to Jacob's criticism through approving of what have been criticized to him. The response shows that Miss Peregrine approving the criticism can be seen from the phrase "thought the same thing". She is approving because if she had not known beforehand about him, she will have the same opinion with Emma.

Assertive - Explaining

\begin{tabular}{ll}
\hline Jacob: & I looked at it. She was dressed like a beggar girl and stood holding a chicken. "What's she supposed \\
P- D- & to be?" I asked. "A homeless farmer?" \\
\hline Emma: & Emma pinched me. "She's meant to look natural, like a savage-type person. Jill of the Jungle, \\
P- D- & we called her."
\end{tabular}

The participants from the above dialogue are Jacob and Emma. Jacob is criticizing Fiona's dressing style. The critics can be seen from the phrase "she was dressed like a beggar girl and a homeless farmer?" Furthermore, Emma who is sitting next to him gives response to Jacob that Fiona dresses naturally like a savage girl who lives in the jungle. Emma's response can be categorized as an explanation because she tells Jacob the reason why Fiona dresses like that. The explanations can be seen from the phrases "she's meant to look natural, like a savage-type person. Jill of the jungle, we called her".

Assertive - Answering

\begin{tabular}{ll}
\hline $\begin{array}{l}\text { Dr. Golan: } \\
\text { P+ D+ }\end{array}$ & $\begin{array}{l}\text { Dr. Golan tapped his pen for a moment and then wrote something down. "I hope you're not just } \\
\text { telling me what you think I want to hear." }\end{array}$ \\
\hline Jacob: & "Of course not," I said, my gaze skirting the framed degrees on his wall, all attesting to his \\
P- D+ & $\begin{array}{l}\text { expertness in various sub disciplines of psychology, including, I'm sure, how to tell when an acutely } \\
\text { stressed teenager is lying to you. }\end{array}$ \\
\hline
\end{tabular}

The above dialogue can be categorized as criticism, uttered by Dr. Golan to Jacob. Dr. Golan criticizing Jacob explanation about his experience and he see in his grandfather house. Dr. Golan criticism can be seen from the phrases "I hope you're not just telling me what you think I want to hear". Furthermore, Jacob gives an answer through phrases "of course not".

\begin{tabular}{l} 
Assertive - Declaring \\
\begin{tabular}{ll} 
Emma: & "I'm sorry, Miss. But how was I to know something bad would happen?" \\
P- D- & "I should punish you. However, given the circumstances, it hardly seems worth the effort." She \\
\hline Peregrine: & $\begin{array}{l}\text { raised a hand and smoothed her mentor's white hair. "Miss Avocet would never have left her wards } \\
\text { P+ D- }\end{array}$
\end{tabular} \\
\hline
\end{tabular}

The participants of the above dialogue are Emma and Miss Peregrine. Emma is apologizing for what she did before. She is sneaking out in the night knowing the condition outside are not safe for them. The utterance to show Emma is apologizing can be seen from the phrase "I'm sorry, Miss". Moreover, Miss Peregrine gives a response declaring her punishment for Emma. Miss Peregrine's declaration can be seen from the phrase "I should punish you".

Directive - Confirming

Ship Crew: As we drew nearer the cliffs, I began to notice odd shapes lurking underwater. A passing crewman P+ D+ caught me leaning over the rail to stare at them and said, "Never seen a shipwreck before, eh?"

Jacob: I turned to him. "Really?"

P- D+ 
The participants for the above dialogue are the ship crew and Jacob. Jacob is sailing to the island where his grandfather lives before. The ship crew is criticizing Jacob attitude for seeing so long beneath the ocean. The criticizing can be seen from the phrase "never seen a shipwreck before, eh?" Jacob who is being criticized gives a response "really?" confirming what he see is a shipwreck or not.

Directive - Command

\begin{tabular}{ll}
\hline Jacob: & "I can't just disappear. My dad will flip out." \\
P- D- & \\
\hline Peregrine: & She frowned. "In that case, you must at least spend the night. I insist upon it." \\
P+ D- &
\end{tabular}

The participants for the above dialogue are Jacob and Miss Peregrine. Jacob is criticizing Miss Peregrine suggestion to stay in the loop with them until the condition back to safe again. The phrase to show the criticism is "I can't just disappear. My dad will flip out". Miss Peregrine as his hearer gives a commanding response to Jacob through phrase "you must at least spend the night and I insist upon it".

Directive - Asking

\begin{tabular}{ll} 
Dad: & "It was a lot more than just one Halloween," he grumbled. "Really, Jake, you were closer to him than \\
P+ D- & I ever was. I don't know-there was just something unspoken between the two of you." \\
\hline Jacob: & I didn't know how to respond. Was he jealous of me? "Why are you telling me this?" \\
P- D- &
\end{tabular}

The above dialogue is between Jacob and his father (Dad). Dad is criticizing Jacob, because he is closer to his grandfather rather than his grandfather to his father. The criticizing utterance is "really, Jake, you were closer to him than I ever was". Jacob response his father criticism by asking question in phrase "why are you telling me this?"

Directive - Suggesting

\begin{tabular}{ll}
\hline Emma: & Emma began to protest, but Miss Peregrine shut her down with a withering glare. "Oh, all right," \\
P- D- & Emma sighed, "but don't say I didn't warn you." And with a few tugs at the knot, the rope fell away. \\
\hline Peregrine: & "You'll have to pardon Miss Bloom," said Miss Peregrine as I rubbed at my chafed wrists. "She has \\
P+ D- & a certain flair for the dramatic."
\end{tabular}

The above dialogue is between Emma and Miss Peregrine. Emma is criticizing Miss Peregrine action to let loose Jacob which is chafed. The phrase to show the criticism is "but don't say I didn't warn you". Miss Peregrine as her hearer gives response of the criticism by suggesting to Jacob to pardon Emma. The phrase to show the suggestion is "you'll have to pardon Miss Bloom".

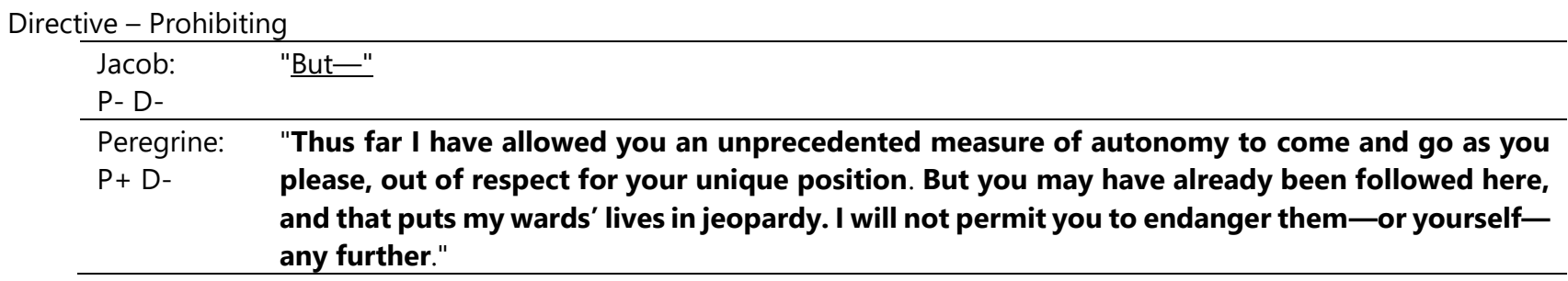

The above dialogue is between Jacob and Miss Peregrine. Jacob is criticizing Miss Peregrine command to stay with them in the loop. The phrase to indicate the criticism is "but-". Furthermore, Miss Peregrine response was prohibiting Jacob to go as he pleases. The phrase to indicate the prohibition is "thus far I have allowed you an unprecedented measure of autonomy to come and go as you please..." in the above dialogue.

Commissive - Promising

\begin{tabular}{ll}
\hline Emma: & Emma shook her head. "ls that really what you think?" \\
P- D- & "If I could do something spectacular like you, don't you think I would've noticed by now?" \\
\hline Jacob: & \\
P- D- &
\end{tabular}


The participants of the above dialogue are Emma and Jacob. Emma is criticizing Jacob for thinking that he was just a normal child not like his grandfather. The phrase to indicate the criticism is "is that really what you think?" Furthermore, Jacob gives a promising response in the phrase "If I could do something spectacular like you, don't you think I would've noticed by now?" in the above dialogue.

Commissive - Rejecting

\begin{tabular}{ll}
\hline Jacob: & "Don't you understand?" I said angrily. "Boats aren't running. Those people in town are stuck. My \\
P- D- & $\begin{array}{l}\text { father is stuck. If there really is a wight, and it's who I think it is, he and my dad have almost gotten } \\
\text { into one fight already. If he just fed a total stranger to a hollow, who do you think he's going after }\end{array}$ \\
& next?" \\
\hline $\begin{array}{l}\text { Peregrine: } \\
\text { P+ D- }\end{array}$ & $\begin{array}{l}\text { Her face was like stone. "The welfare of the townspeople is none of my concern," she said. "I won't } \\
\text { endanger my wards. Not for anyone." }\end{array}$ \\
\hline
\end{tabular}

The participants of the above dialogue are Jacob and Miss Peregrine. Jacob is criticizing Miss Peregrine action, because she does not want to help to safe his family. The utterance to indicate the criticizing is "don't you understand" and "boat aren't running". Furthermore, Miss Peregrine gives a response rejecting Jacob's request. The phrase to show Miss Peregrine's rejection is "the welfare of the townspeople is none of my concern".

Commissive - Offering

\begin{tabular}{ll}
\hline Emma: & She threw her arms around my neck. "I missed you," she said. "Sorry about before." \\
P- D- & \\
\hline Jacob: & "I am, too," I said, patting her back awkwardly. "So, let's talk." \\
P- D- &
\end{tabular}

The participants of the above dialogue are Emma and Jacob. Emma is apologizing to Jacob for what she did previously to Jacob. The phrase to show the apologizing utterance is "sorry about before". Jacob gives a response and offering Emma to talk with him. The phrase to indicate the offering is "so, let's talk".

Expressive - Criticizing

\begin{tabular}{ll}
\hline Ricky: & "Maybe he stepped out," Ricky said, grinning. "Hot date." \\
P- D- & \\
\hline Jacob: & "Go ahead and laugh," I said. "He's got a better shot than we do any night of the week. This place is \\
P- D- & crawling with eligible widows." I joked only to calm my nerves. The quiet made me anxious. \\
\hline
\end{tabular}

The participants of the above dialogue are Ricky and Jacob. Ricky and Jacob are childhood friends. Ricky is criticizing Jacob's grandfather because he is nowhere to be found in his home. The phrases to show the criticizing utterances are "maybe he stepped out" and "hot date". Furthermore, Jacob responses Ricky criticize through criticizing him back. Jacob criticism can be indicating in phrase "go ahead and laugh".

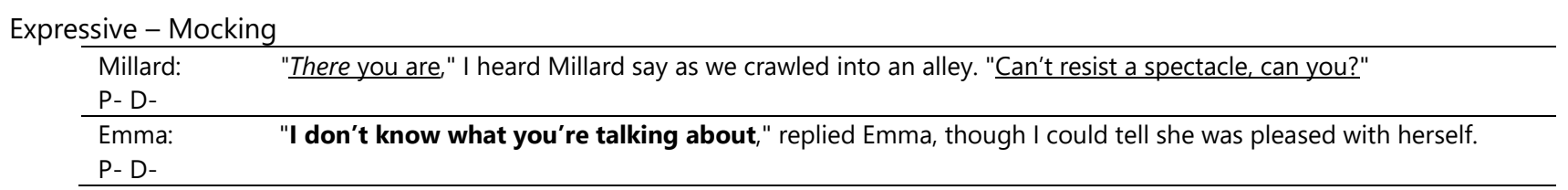

The above dialogue is between Millard and Emma. They are friend in Miss Peregrine's orphanage. Millard is criticizing Emma because he finds her in the alley, the place that he least expected. The phrases to indicate that Millard is criticizing Emma are "there you are" and "can't resist a spectacle, can you?" Furthermore, Emma gives a response to mocking him. The phrase to shows that Emma mocking Millard is "I don't know what you're talking about".

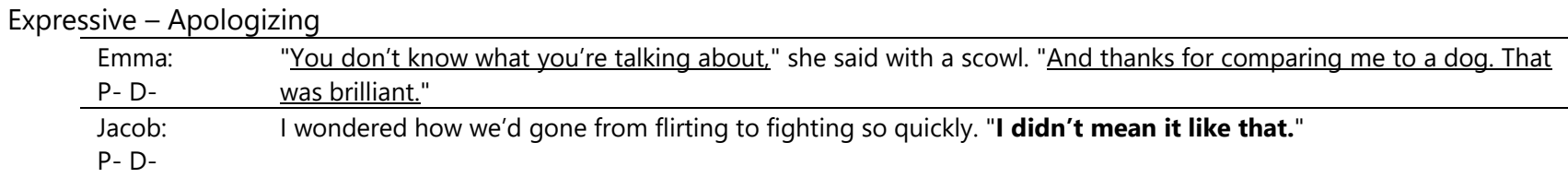


The above dialogue is between Emma and Jacob. They are talking about Jacob who wants to take Emma to see his father. Emma is criticizing Jacob because he does not know the reason why they always stay in the loop. The phrases to show that Emma is criticizing Jacob are "you don't know what you're talking about" and "...thanks for comparing me to a dog...". Moreover, because of her criticism, Jacob gives an apologizing response through phrase "I didn't mean it like that".

Expressive - Blaming

\begin{tabular}{ll}
\hline Emma: & Emma gasped. "Seduce? Oh, please, don't think that of me, Jacob. I couldn't bear it." \\
P- D- & \\
\hline Peregrine: & "I fear you've badly misjudged us," said Miss Peregrine. "As for seducing you, what you've seen is \\
P- D- & how we live. There has been no deception, only the withholding of a few facts." \\
\hline
\end{tabular}

The participants of the above dialogue are Emma and Miss Peregrine. Emma is criticizing Jacob through employing phrase "seduce? Oh, please, don't think that of me..." in the above dialogue. Furthermore, Miss Peregrine as her hearer gives a blaming response through phrase "I fear you've badly misjudged us".

\begin{tabular}{l} 
Expressive - Satirizing \\
\begin{tabular}{ll} 
Jacob: & "I'm sorry. I shouldn't be in here." \\
P- D- & "I'm bloody well aware of that," she said, "but by all means, don't let me interrupt your reading." \\
\hline Emma: & She stamped over to her chest of drawers, yanked one out, and threw it clattering to the floor. "While \\
P- D- & you're at it, why don't you have a look through my knickers, too!"
\end{tabular} \\
\hline
\end{tabular}

The participants of the above dialogues are Jacob and Emma. They are talking about Jacob who is entering Emma's room without having her permission. Jacob is apologizing to Emma because he goes to her room without her permission by exploiting phrases "I'm sorry and I shouldn't be in here". In addition, responding Jacob apology, Emma is satirizing him using phrases "I'm bloody well aware of that and but by all means, don't let me interrupt your reading".

\begin{tabular}{l} 
Expressive - Surprising \\
\begin{tabular}{ll}
\hline Jacob: & I forced myself to look at her. "I'm really sorry to have to tell you this ..." \\
P- D- & \\
\hline Emma: & "What? Oh no." \\
P- D- &
\end{tabular} \\
\hline
\end{tabular}

The above dialogue is between Jacob and Emma. They are talking about what happened to Jacob's grandfather. Jacob is apologizing to Emma because he had to tell her the truth about his grandfather's death. Jacob apology can be indicating in "I'm really sorry to have to tell you this" phrase. Herein after, Emma is responding to Jacob's apology with surprising expression in "what? Oh no".

\subsection{Translation Techniques}

Soon after, the researcher found out the response of criticizing and apologizing expressive speech acts the next step is to find out the translation techniques used in translating those responses of speech acts using theory proposed by Molina \& Albir (2002:509). Those translation techniques found out from the responses can be seen on the table below:

Table 2. Translation Techniques Used

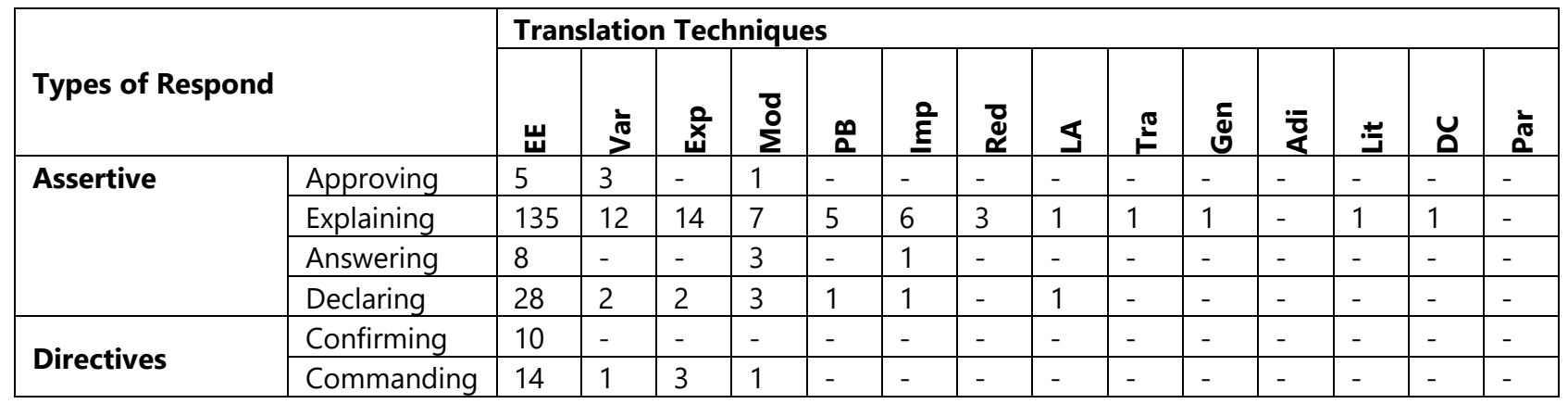




\begin{tabular}{|c|c|c|c|c|c|c|c|c|c|c|c|c|c|c|c|}
\hline & Asking & 5 & 1 & 1 & - & 1 & - & - & - & - & - & - & - & - & - \\
\hline & Suggesting & 41 & 1 & 3 & 2 & 6 & 1 & - & - & - & - & - & - & - & 2 \\
\hline & Prohibiting & 16 & 4 & 1 & - & - & - & - & - & - & - & - & 1 & - & - \\
\hline \multirow{3}{*}{ Commissive } & Promising & 8 & 3 & - & 1 & - & - & - & - & - & - & 1 & - & - & - \\
\hline & Rejecting & 8 & 2 & 2 & - & - & - & - & - & - & - & - & - & - & - \\
\hline & Offering & - & - & - & - & - & - & - & - & - & - & - & - & 1 & - \\
\hline \multirow{7}{*}{ Expressive } & Criticizing & 8 & - & - & 1 & 1 & 1 & - & - & - & - & - & - & - & - \\
\hline & Mocking & 1 & - & - & 2 & - & - & - & - & - & - & - & - & - & - \\
\hline & Apologizing & 5 & 1 & - & 1 & - & - & - & - & - & - & - & - & - & - \\
\hline & Blaming & 4 & 2 & - & - & - & - & - & - & - & - & - & - & - & - \\
\hline & Satirizing & 11 & 1 & 1 & 1 & - & - & - & - & - & - & - & - & 1 & - \\
\hline & Surprising & 3 & - & - & - & - & - & - & - & - & - & - & - & - & - \\
\hline & Total & 310 & 33 & 27 & 23 & 14 & 10 & 3 & 2 & 1 & 1 & 1 & 2 & 3 & 2 \\
\hline
\end{tabular}

*EE (Established Equivalent); Var (Variation); Exp (Explicitation); Mod (Modulation); PB (Pure Borrowing); Imp (Implication); Red (Reduction); LA (Linguistic Amplification); Tra (Transposition); Gen (Generalization); Adi (Addition); Lit (Literal); DC (Discursive Creation); dan Par (Paraphrase)

Established Equivalent
Source Text
: Go ahead and laugh, I said
Target Text
: Silakan tertawa, kataku

The context of the above data is Jacob and Ricky visiting Jacob's grandfather. They found that no one is in the house. Ricky is criticizing Jacob's grandfather because he is nowhere to be found in the house. Furthermore, Jacob gives a response by criticizing him. Furthermore, the translator use established equivalent to translate the word laugh into tertawa. The word tertawa is an equivalent term of laugh in the Source Language.

Variation

Source Text : : I'm serious. Don't you think this could mean that maybe he wasn't cheating on Grandma, after all?

Target Text : : Aku serius. Bisa saja ini berarti dia bukannya berselingkuh, kan?

The context of the above data is Jacob telling his father all the information about his grandfather. Furthermore, the above example shows the use of variation translation technique in translating the word I'm in the Source Language into aku in the Target Language. Variation is used when the translator want to change the linguistic elements of the word I'm with the word $\boldsymbol{a k u}$.

Explicitation

Source Text : : My dad and I have the upstairs rooms, I said.

Target Text : : Ayahku dan aku menyewa kamar di atas, kataku.

The context of the above data is the man critizing Jacob because he rushes in the upstair. Jacob does not know that he has entered the loop and it brought him back to the time before the city was bombed. Herein after, the translator used explicitation to provides more detail information of the word have in the Source Language into menyewa in the Target Language. The equivalent term for the word menyewa originally is rent. However, according to the context, the word have can be assumed to menyewa.

Modulation

Source Text

Target Text

\section{Don't worry about it. \\ Tidak apa - apa.}

The context for the above data is Jacob talking to Emma to clear the misunderstanding between them. Furthermore, the researcher found that the translator used modulation to translate phrase don't worry about it into tidak apa - apa. Modulation is used to change the lexical point of view in relation to the source text.

Pure Borrowing

\begin{tabular}{|l|l|}
\hline Source Text & : Golan knew everything but how to find you, I said. \\
\hline Target Text & : Golan tahu segalanya, kecuali cara menemukan kalian, kataku. \\
\hline
\end{tabular}

The above data context is Enoch criticizing Jacob because he shows their pictures to the other person who is accidentally their enemy, Golan. Herein after, the translator uses pure borrowing translation technique to translate the word Golan from the Source 
language into Golan in the Target Language. Pure borrowing translation technique is used when the translator takes a word straight from another language without any change.

Implicitation

\begin{tabular}{|l|l|}
\hline Source Text & : Go ahead and laugh, I said. \\
\hline Target Text & : Silakan tertawa, kataku. \\
\hline
\end{tabular}

The context of the above data is Jacob and Ricky visiting Jacob's grandfather. They found that no one is in the house, Ricky criticizing Jacob's grandfather because he is nowhere to be found in the house. Furthermore, Jacob gives a response by criticizing him. Furthermore, the translator use implicitation translation technique to make the word and not clearly presented in the target language.

Reduction

\begin{tabular}{|l|l|}
\hline Source Text & :You're right, Dad. Dr. Golan did help me. \\
\hline Target Text & : Dad benar. Dr. Golan memang sudah membantuku. \\
\hline
\end{tabular}

The context for the above data is Jacob and his father talking about Dr. Golan's contribution for the opportunity. Furthermore, the above data shows the usage of reduction translation technique in translating the phrase you're right, Dad in the ST into dad benar in TT. The use of reduction translation techniques is to suppress the information of you from Source Language into Target Language.

Linguistic Amplification

\begin{tabular}{|l|l|}
\hline Source Text & : I am. \\
\hline Target Text & : Aku serius. \\
\hline
\end{tabular}

The context for the above data is Emma wants to go to the outside of the loop with Jacob. Furthermore, the above data shows the use of linguistic amplification translation technique. Linguistic amplification is used to add linguistic element in the Target Language. The translator add linguistic element of serius in the Target Language.

Transposition

\begin{tabular}{|l|l|}
\hline Source Text & $\begin{array}{l}\text { : Look at the state of this place. Look at the headmistress. We had a damn good run here, but } \\
\text { it's over. }\end{array}$ \\
\hline Target Text & $\begin{array}{l}\text { : Coba Ihat keadaan tempat ini. Lihat Ibu Kepala Sekolah. Kita pernah hidup bahagia di sini, } \\
\text { tapi sekarang sudah berakhir. }\end{array}$ \\
\hline
\end{tabular}

The context for the above data is Enoch asking Emma the reason why they cannot live here anymore after these accidents. Herein after, the above data show the usage of transposition translation technique in translating we had a damn good run here in Source Language into kita pernah hidup bahagia di sini in the Target Language. Transposition is used to change the grammatical category of a damn good run here in Source Language into hidup bahagia di sini in Target Language.

Generalization

\begin{tabular}{|l|l|}
\hline Source Text & $\begin{array}{l}\text { : People come to sideshows to see stunts and tricks and what-all, and as far as anybody knew that's exactly } \\
\text { what we showed them. }\end{array}$ \\
\hline Target Text & $\begin{array}{l}\text { : Orang - orang datang untuk melihat pertunjukkan aneh - aneh dan tipuan, dan lain - lain, dan sejauh yang } \\
\text { mereka ketahui, itulah yang kami tampilkan. }\end{array}$ \\
\hline
\end{tabular}

The context of the above data is Jacob asking to Emma about the reason why their show is full of audience even though they need to hide their peculiarities. Furthermore, the researcher find that the translator use generalization translation technique to generalize the term people from Source Language into orang - orang in the Target Language.

Addition

\begin{tabular}{|l|l|}
\hline Source Text & : If I could do something spectacular like you, don't you think I would've noticed by now ? \\
\hline Target Text & $\begin{array}{l}\text { : Seandainya aku bisa melakukan sesuatu yang luar biasa seperti dirimu, tentunya aku sudah tahu sejak } \\
\text { dulu, bukan? }\end{array}$ \\
\hline
\end{tabular}


The context of the above data is Jacob asking to Emma why he has not known his own peculiarity. Furthermore, the above data show the use of addition translation technique to translate the word spectacular from Source Language into sesuatu yang luar biasa in Target Language. The translator use addition to add linguistic information of sesuatu yang in the Target Language.

Literal

\begin{tabular}{|l|l|}
\hline Source Text & : Not in this rain," I said, "and not if you can't see it ! \\
\hline Target Text & : Tidak dalam hujan ini," kataku, "apalagi kau tidak bisa melihatnya! \\
\hline
\end{tabular}

The context for the above examples is Emma criticizing Jacob decision to let his friends go first while he fights the wight alone. Furthermore, the researcher found out that the translator literary translates the word not from Source Language into tidak in Target Language.

Discursive Creation

\begin{tabular}{|l|l|}
\hline Source Text & $\begin{array}{l}\text { : I'm bloody well aware of that," she said, "but by all means, don't let me interrupt your reading." } \\
\text { She stamped over to her chest of drawers, yanked one out, and threw it clattering to the floor. } \\
\text { "While you're at it, why don't you have a look through my knickers, too! }\end{array}$ \\
\hline Target Text & $\begin{array}{l}\text { : Ya, bisa kulihat jelas," kata Emma, "tapi silakan saja, jangan sampai aku mengganggu } \\
\text { keasyikanmu membaca." Dengan marah dia melangkah ke lemari lacinya, menyentakkan salah } \\
\text { satu laci, dan melemparkannya ke lantai dengan suara berisik. "Dan mumpung kau sudah } \\
\text { membukanya, kenapa tidak sekalian melihat - lihat pakaian dalamku juga! }\end{array}$ \\
\hline
\end{tabular}

The context of the above data is Emma satirizing Jacob's behavior for intruding to Emma's room. Furthermore, the above dialogue indicates the use of discursive creation translation technique in translating phrase I'm bloody well aware of that into ya, bisa kulihat jelas. Discursive creation translation technique is used to establish a temporary equivalence that is totally unpredictable out of context.

Paraphrase

\begin{tabular}{|l|l|}
\hline Source Text & $\begin{array}{l}\text { : You'll have to pardon Miss Bloom," said Miss Peregrine as I rubbed at my chafed wrists. "She } \\
\text { has a certain flair for the dramatic." }\end{array}$ \\
\hline Target Text & $\begin{array}{l}\text { : Kau harus memaklumi Miss Bloom," Miss Peregrine berkata, sementara aku menggosok - gosok } \\
\text { kedua pergelangan tanganku yang lecet. "Dia menyukai hal - hal yang dramatis." }\end{array}$ \\
\hline
\end{tabular}

The context of the above data is Miss Peregrine give a suggestion to Jacob to let Emma go for once even though she had chafed him before. Furthermore, the above dialogue indicates the usage of paraphrase translation technique in translating the phrase she has a certain flair for the dramatic into dia menyukai hal - hal yang dramatis. Paraphrase translation technique is used in restating the phrases in a different way in TT.

\subsection{Translation Quality Assessment on Accuracy}

After the researcher found out the responses and the translation techniques, the researcher measure the accuracy of the translated response. The majority responses are considered accurate with average score of 2.77 and there are only two responses that belong to inaccurate, such as prohibiting and offering speech acts. The complete information about the accuracy of the translated responses can be seen in the table below:

Table 3. Translation accuracy

\begin{tabular}{|l|l|c|}
\hline \multirow{2}{*}{ Types of Response } & \multicolumn{2}{c|}{$\begin{array}{c}\text { Accuracy } \\
\text { Average }\end{array}$} \\
\hline Assertive & Approving & \multicolumn{1}{|c|}{3} \\
\cline { 2 - 3 } & Explaining & 2.89 \\
\cline { 2 - 3 } & Answering & 3 \\
\cline { 2 - 3 } & Declaring & 3 \\
\hline \multirow{4}{*}{ Directives } & Confirming & 3 \\
\cline { 2 - 3 } & Commanding & 3 \\
\cline { 2 - 3 } & Asking & 3 \\
\cline { 2 - 3 } & Suggesting & 3 \\
\cline { 2 - 3 } & Prohibiting & 1.5 \\
\hline
\end{tabular}




\begin{tabular}{|l|l|c|}
\hline \multirow{4}{*}{ Commissive } & Promising & \multicolumn{1}{|c|}{3} \\
\cline { 2 - 3 } & Rejecting & 3 \\
\cline { 2 - 3 } & Offering & 1 \\
\hline \multirow{4}{*}{ Expressive } & Criticizing & 3 \\
\cline { 2 - 3 } & Mocking & 3 \\
\cline { 2 - 3 } & Apologizing & 3 \\
\cline { 2 - 3 } & Blaming & \multicolumn{1}{|c|}{3} \\
\cline { 2 - 3 } & Satirizing & \multicolumn{2}{|c|}{3} \\
\cline { 2 - 3 } & Surprising & $\mathbf{2 . 7 7}$ \\
\hline Average & & $\mathbf{2 . 7 5}$ \\
\hline
\end{tabular}

The table above shows the translation qualities for each category of utterances which accommodate a response for expressive criticizing and apologizing speech act.

Accurate

\begin{tabular}{|l|l|}
\hline Source Text & : I might have thought the same thing, if I hadn't observed you beforehand. \\
\hline Target Text & : Aku pun mungkin akan mengira begitu, seandainya aku belum pernah mengamatimu. \\
\hline
\end{tabular}

The context of the above example is Jacob listening to Miss Peregrine explanation why he was treated poorly. In addition, Jacob also being accused to be something that he did not know before. Furthermore, Jacob asking Miss Peregrine to explain it in detail and why he was treated poorly.

The above example in the bold is accurate because there is no distortion of meaning in translating utterance which accommodates response of expressive speech act. In addition, the raters also give score of 3 which means it is accurate.

Less Accurate

\begin{tabular}{|l|l|}
\hline Source Text & $\begin{array}{l}\text { : Nobody suspected a thing, she said. People come to sideshows to see stunts and tricks and } \\
\text { what-all, and as far as anybody knew that's exactly what we showed them. }\end{array}$ \\
\hline Target Text & $\begin{array}{l}\text { : Tidak ada yang curiga, sahutnya. Orang - orang datang untuk melihat pertunjukkan aneh } \\
- \text { aneh dan tipuan, dan lain - lain, dan sejauh yang mereka ketahui, itulah yang kami } \\
\text { tampilkan. }\end{array}$ \\
\hline
\end{tabular}

The context of the above example is Jacob questioning why they show the people what they are capable of. Even though, they have to stay undercover avoiding wight and their companions. The above example is less accurate because there are distortions of meaning in the Target Language. In addition, the translator deleted some information from the Source Language. Furthermore, the raters give score 2 for the data.

Not Accurate

\begin{tabular}{|l|l|}
\hline Source Text & : I am, too," I said, patting her back awkwardly. "So, let's talk. \\
\hline Target Text & $\begin{array}{l}\text { : Aku juga kangen," kataku, sambil menepuk - nepuk punggungnnya dengan kikuk. "Nah, ayo } \\
\text { kita bicara. }\end{array}$ \\
\hline
\end{tabular}

The context of the above example, Jacob went back to the loop after his father go to bed.

The above example is not accurate because the translated utterance is out of context. Furthermore, because the translated utterance is out of context, the rater agreed to give score 1 to indicate inaccurate.

\section{Conclusion}

From the above findings and discussions, it was found that from the criticizing and apologizing expressive speech acts there are four responses. These are Assertive (approving, explaining, answering, and declaring); Declaratives (confirming, commanding, asking, suggesting, and prohibiting); Commissive (promising, rejecting, and offering) and Expressive (criticizing, mocking, apologizing, blaming, satirizing, and surprising). Moreover, it was also found that the translator uses fourteen translation techniques. The translation techniques which are mostly used are established equivalent, variation, explicitation and others translation techniques [discuss this further]. In addition, because the commonly used translation technique is established equivalent, it affects the translation accuracy quality with the score of 2.77 which mean accurate. Henceforth, the accuracy score is not full number of 3 because there are other translation techniques which decrease the quality, they are reduction, literal, and discursive creation. 


\section{References}

[1] Creswell, J.W. (2003). Research design: Qualitative, quantitative, and mixed method approaches. Thousand Oaks, Calif: Sage Publications.

[2] Djatmika. (2016). Mengenal pragmatik yuk!?.Yogyakarta: Pustaka Pelajar.

[3] Fitriana, I. (2014). Analisis teks dan kualitas terjemahan tindak tutur ekspresif dalan novel Stealing Home (Hati yang Terenggut) karya Sherryl Wood. Tesis. Universitas Sebelas Maret: Surakarta.

[4] Hapsari, P.W. (2016). Kajian terjemahan kalimat yang merepresentasikan tindak tutur asertif menjawab dalam dua versi terjemahan novel Pride and Prejudice. Tesis: Universitas Sebelas Maret: Surakarta.

[5] Limyana. (2013). Terjemahan tindak tutur asertif tokoh utama dalam novel the Kite runner karya khaled hosseini dan dampaknya terhadap kualitas terjemahannya. Tesis.Universitas Sebelas Maret: Surakarta.

[6] Mansur, A.A. (2014). Kualitas terjemahan bentuk mitigasi pada tindak tutur memerintah (commanding) dalam dua seri novel Harry Potter (sebuah kajian terjemahan dengan pendekatan pragmatik). Tesis: Universitas Sebelas Maret Surakarta.

Molina, L \&Albir, A.H. (2002). "Translation Technique Revisited: A Dynamic and Functionalist Approach". Meta, Vol. XLVII, No. 4, 499-512

[7] Nababan, M. R., Ardiana Nuraeni, Sumardiono. (2012). Pengembangan Model Penilaian Kualitas Terjemahan, Kajian Linguistik dan Sastra. Vol. 24, no 1, Juni 2012,39-57.

[8] Newmark, P. (1988). A textbook of translation. London: Prentice Hall.

[9] Nida, E.A., \& Taber, C.R. (1982). The theory and practice of translation. Leiden: E.J. Brill.

[10] Poerdawarminta. (1999). Psikologi komunikasi. Jakarta: UT.

[11] Putri, N.S. (2017). Analisis terjemahan kalimat yang mengakomodasi tindak tutur komisif pada novel insurgent karya veronica roth. Tesis. Universitas Sebelas Maret: Surakarta.

[12] Searle, J. (1979). Expression and meaning: Studies in the theory of speech act. Cambridge, England: Cambridge University.

[13] Spradley, J.P. (1980). Participant observation. New York: Holt, Rinehart and Winston.

[14] Subandi A. (1982). Psikologi sosial. Jakarta. Bulan Bintang.

[15] Wahyudi. (2016). Analisis terjemahan tindak tutur giving compliment pada Subtitle film twilight series dan kualitas terjemahannya. Tesis. Universitas Sebelas Maret: Surakarta.

[16] Yule, G. (1996). The study of language. Great Britain: Cambridge University Press. 